\title{
THE ROLE OF CERTIFICATION IN THE BRAZILIAN FRUIT SECTOR*
}

\author{
Andrea Cristina Dorr ${ }^{*}$
}

Ulrike Grote $^{* * *}$

\begin{abstract}
Certification systems play an important role in any market that is burdened with a high degree of information asymmetry and quality uncertainty. Thus, producers and exporters of fresh fruit in developing countries like Brazil are increasingly required to demonstrate the safety and traceability of their produce up to the consumption stage. This paper aims at presenting a comparative analysis of the different certification schemes applied to fruit production in Brazil. A survey of 303 grape and mango farmers was conducted in 2006 in the Juazeiro and Petrolina regions of the São Francisco Valley. The results of the certification schemes adopted by grape farmers show that GlobalGAP certified ones have higher productivity. The income of farmers with one certificate is higher than that of those with two certificates. The comparative analysis of small and medium farms concludes that there is no evidence of the marginalization of small farmers.
\end{abstract}

Key words: fruit, certification, European Union

* Article sent on December 5, 2008, and approved on July 10, 2009. The authors would like to thank the German Academic Exchange Service (DAAD) and the German Ministry for Economic Cooperation and Development (BMZ) for their financial support.

** Bachelor in Economics at the Federal University of Santa Maria (RS), Master Degree in Applied Economics (ESALQ/USP) and PhD in Economics (ZEF) at the University of Hannover, in Germany. Ms. Dorr was a professor at the Centro Universitário Franciscano (UNIFRA) in 2004 and 2005. She is currently working as a trainee at the United Nations Industrial Development (Unido) in Vienna, Austria, email: andreadoerr@yahoo.com.br

*** Ulrike Grote studied agricultural economics at the University of Kiel. After receiving her PhD. from Kiel in 1994, she worked at the OECD in Paris and at the Asian Development Bank in Manila. From 1998 until 2006, Ulrike Grote was the senior researcher at the Center for Development Research (ZEF) in Bonn. In October 2006, she was appointed as professor and director of the Institute for Environmental Economics and World Trade at the Leibniz University of Hannover. Her research focuses on international agricultural trade, environmental and development economics. e-mail: grote@iuw.uni-hannover.de 


\section{O PAPEL DA CERTIFICAÇÃo NA \\ FRUTICULTURA BRASILEIRA}

RESUMO Sistemas de certificação desempenham um papel importante em mercados que apresentam um alto nível da assimetria de informação e incerteza na qualidade. Por isso, produtores e exportadores de frutas frescas de países em desenvolvimento como o Brasil são constantemente requisitados a demonstrar segurança e rastreabilidade da produção até o estágio final de consumo. Este artigo tem como objetivo apresentar uma análise comparativa dos diferentes sistemas de certificação existentes na fruticultura no Brasil. A coleta de dados primários com 303 produtores de uva e manga foi conduzida em 2006 na região de Juazeiro e Petrolina no Vale do São Francisco. Os resultados mostram que produtores de uva que são certificados com GlobalGAP têm maior produtividade. A renda dos produtores com um certificado é maior que a dos que possuem dois certificados. A ánalise comparativa das pequenas e médias propriedades conclui que não há evidência de marginalização de pequenos produtores.

Palavras-chave: frutas; certificação; União Européia

Código JEL: F0; O1; Q10 


\section{INTRODUCTION}

Producers and exporters of fresh fruit and vegetables in developing countries like Brazil are increasingly required to demonstrate the safety and traceability of their produce up to the consumption stage. In order to access international markets such as the European Union (EU) and the United States (US), fruit producers increasingly need to meet the buyer's requirements and comply with certification systems. In Brazil, these specific certification systems are the Integrated Fruit Production (PIF), GlobalGAP, Fairtrade, and Organic certification schemes. It is not clear the impact that these certification schemes have on Brazilian fruit farmers. There is some evidence that certification contributes positively to the development of specific export sectors in developing countries. In fact, the Brazilian export market is still relatively underdeveloped, with an export share of only $2.4 \%$ of the total produced volume. Brazil is the third largest fruit producer among developing countries, behind China and India. Its total production was 43.8 million tons in 2004, representing $3.2 \%$ of the production of all developing countries. However, it is estimated that only about $2 \%$ of the country fruit production (in terms of volume) is exported, generating US\$370 million (Brazilian Fruit Institute - Ibraf, 2004).

Grape and mango exports have been the most successful cases, with about 260,000 and 550,000 tons each being cultivated. The regions of Petrolina and Juazeiro, which are part of the São Francisco River basin, is responsible for this export performance. This region produced $99 \%$ and $88 \%$ of the country's grape and mango exports (Ibraf, 2004). Valexport (2006) estimates that the sector directly generates a total of 240,000 jobs and, indirectly, 960,000 jobs in the region.

Given the trend towards tighter food safety requirements in international markets, in 1999, Brazil started to develop the Integrated Fruit Production (PIF) scheme, a national quality assurance program. The Ministry of Agriculture, Food Supply, and Livestock (Mapa) requested the Brazilian Agricultural Research Company (Embrapa) to further develop the scheme for implementation. The pilot projects involved apples, grapes, mangoes and citrus fruits. As part of the Fruit Production Development Program (Profruta), this system contributed to strengthen the ties between the public and 
private sectors, aiming at improving quality, competitiveness and the share of national fruit at the international level (Andrigueto et al., 2002).

Thus, certification has become increasingly relevant as a marketing signal for the agribusiness over the past few years, especially in the fruit sector. Substantial parts of many value chains are now certified by standards such as GlobalGAP, Fair Trade, Integrated Fruit Production and Organic. The fruit and vegetable sectors are seen as sectors in which small producers are able to participate due to their low demand on land, as well as their high labor requirements.

The purpose of this paper is to present a comparative analysis of the different certification schemes which are applied to fruit production in Brazil and to highlight their importance to enhance the competitiveness of the chain. These are GlobalGAP, Integrated Fruit Production (PIF), and Fairtrade.

\section{LITERATURE REVIEW}

\subsection{Certification: definition and purposes}

Certification is a procedure by which a third party gives written assurance that a product, process or service is in conformity with certain standards. Thus, certification can be seen as a form of communication along the supply chain, as the certificate demonstrates to the buyer that the supplier complies with certain standards (International Organization for Standardization - ISO, 1996). Similarly, "certification is the (voluntary) assessment and approval by an (accredited) party on an (accredited) standard." (Meuwissen et al., 2003, p. 54.) Schiefer (2003, p. 4) mentions that "sustainable and effective certification must allow clearly identifiable segmentation throughout, e.g. branding of products from clearly specified supply chains.”

In the agricultural and food industry sector, certification refers to all kinds of food products (juices, cereals, and grains, including rice, and even alcoholic beverages, such as wine, etc., sugar, meat, dairy products, and eggs) which have been produced based on organic or bio-dynamic farming technologies or on Integrated Pest Management (IPM). Other non-food agricultural products like animal feeds (for production of organic meat, dairy products, and eggs), grain seeds, natural pesticides and insecticides, 
cosmetics and textiles (cotton, leather, and leather goods) may also be certified if they meet certain environmental criteria (Basu et al., 2004).

According to El-Tawil (2002), certification is the process by which buyers assess the compliance with defined standards, and is typically undertaken by a third party agency which the buyer recognizes as competent. A crucial issue for low and middle-income countries is the establishment of certification capacity and parallel institutions through which certification bodies are accredited.

The purpose of certification is to reach a defined performance and to make this perceptible to stakeholders. Stakeholders may include consumers, other customers, governments, risk-financing parties such as banks and insurance companies, or society as a whole. The company itself can also be a stakeholder, since the certification of food safety and traceability systems gives organizations a tangible proof of good practice, and is also a tool for due-diligence defense in case of product safety (Henson \& Holt, 2000). For stakeholders to regard certification as a valuable tool, they must trust the certification scheme as well as the certifying party. Also, there should be regular tests or audits (usually specified in the certification scheme) to verify whether the certified party still reaches the agreed performance level.

On the one hand, implementing food safety standards can increase costs for firms. On the other hand, firms have incentives to protect their reputation, and so they might implement state-of-the-art food safety practices without any prodding from the government. Additionally, as consumers might be willing to pay more for foods that they perceive as safer, firms have another incentive to implement stricter food safety regimes. The higher prices consumers are willing to pay could compensate firms for the costs of food safety provision. A firm will adopt more stringent food safety practices if the cost is smaller than the resulting benefit to the firm, in the form of reduced risk of losses, reduced liability, and higher consumer willingness to pay for the safer foods (Mitchell, 2003).

Certification can act to impede exports, either because explicit bans are placed on imports of particular products or because the cost of compliance with requirements diminishes export competitiveness. Standards can therefore be a source of competitive advantage for the developing countries if they upgrade capacity and make the necessary adjustments in the structure 
and operation of their supply chains. For many high-value foods, including fruits and vegetables, the challenges of international competitiveness have moved beyond price and basic quality parameters to greater emphasis on food safety. Indeed, rising food safety standards serve to accentuate supply chain strengths and weaknesses, and thus affect the competitive positions of countries and distinct market participants (Henson \& Jaffee, 2004).

\subsection{Different types of standards}

Setting international standards has proven difficult due to the variety of circumstances that exist around the world. This is especially true for agricultural products, which have to respond to differences in climate, soils, and ecosystems, and are an integral part of cultural diversity. Hence, environmental and social standards are, often normative standards, i.e. generic standards or guidelines used as a framework by local standard-setting or certification bodies to formulate more specific standards. Nevertheless, standards developed in one particular country or geographical area may discriminate against producers of other countries or areas if they do not take into account different local conditions (FAO, 2003).

The most widely-applied general standards systems are the Hazard Analysis Critical Control Points (HACCP), and the ISO 9000, required by the food industry. The HACCP system identifies specific hazards and establishes control systems that focus on prevention rather than on end-product testing. In contrast, ISO standards are specific to a particular product, material or process. ISO 9000 examines if regulations for items are met. Thus, HACCP is a food safety meta-system, while ISO 9000 is a quality management system. Both systems are applied by the processing food industries (Lee, 2006).

Hobbs, Fearne \& Spriggs (2002) compare the incentive structures in the food safety legislation and business strategies in the private sector in the United Kingdom (UK), Canada, and Australia. The comparisons highlight the importance of incentives for changes in determining the respective roles of public policy and private sector responses to food safety issues.

Henson (2006) distinguishes between standards as being mandatory, voluntary, and de facto. Mandatory or regulatory standards, named technical regulations by the Technical Barriers to Trade (TBT) Agreement, are standards set by public institutions whose compli0ance is mandatory in the 
legal sense. Voluntary consensus standards arise from a formal coordinated process involving participants in a market with or without the government's participation. Finally, de facto standards arise from an uncoordinated process of private firms' market-based competition. These standards refer to a set of specifications that aim at gaining market share through authority or influence.

According to Schulze et al. (2006), there are public and private certification systems. Governmental certification systems, for instance, serve the consumers' protection purposes by providing quality labels to improve market transparency (e.g. organic farming). Public certification systems help to prevent mislabeling through laws and fines enforced by public authorities. However, most certification schemes are privately organized. Certification procedures tend to be different depending on their purposes, whether they are meant for consumer marketing or to meet the demands of institutional buyers.

Likewise, the World Trade Organization (WTO, 2005) has also divided standards into private and public. The distinction between them matters when we consider whose interests the standards are set for. It is assumed that the interests of all members of society are considered in the case of public standards, while the private standards are chosen to maximize firms' profits. Thus, private standards are by definition voluntary, while public ones can be either voluntary or mandatory. ${ }^{1}$

\subsection{Information asymmetries}

Information asymmetries occur when producers have information about the characteristics of the goods they produce which consumers do not possess. Buyers are in a disadvantageous position compared to sellers, because the latter are well-informed about the goods or services, as opposed to the buyers. Therefore, standards can increase welfare by removing information asymmetries in markets (WTO, 2005). Thus, on the one hand, the existence of asymmetric information increases the transaction costs, while on the other, it generates private incentives to decrease them. Moreover, food quality and safety standards are voluntarily accepted and applied by firms to improve their competitiveness. This motivation guides firms towards quality assurance systems (Holleran et al., 1999). 
The idea behind certification systems is to reduce existing information asymmetries, especially in the case of goods including credence attributes such as food safety, organic production and animal welfare. In the supply chain, consumers and suppliers are confronted with information uncertainty. Consumers are not able to detect opportunistic behavior. In order to reduce consumers' and suppliers' uncertainty, retailers and brand manufacturers increasingly tend to monitor their suppliers' production process themselves via second party audits (Caswell et al., 1998).

A certification system analysis focusing on its functioning reveals that certification systems include tendencies towards opportunistic behavior. Taking into consideration the great number of customers demanding certificates from their suppliers, producers are constantly under pressure to certify (Schulze et al., 2006). Moreover, Beck \& Walgenbach (2003) emphasize that suppliers perceive certification schemes as externally imposed obligations, instead of being intrinsically motivated quality management systems.

Jahn, Schramm \& Spiller (2005, p. 56) denote that "certification systems and labeling imply multifaceted problems to which the parties involved have paid little attention so far: the central task of certification and the reduction of information asymmetry within the market can be accomplished only if the institutions in charge succeed in assuring certification quality, and thus, the validity of the audit signal." However, the reliability of the quality labels and their effectiveness strongly depend on the type of external audits and their implementation. Usually the control process is carried out by independent certifiers who, in turn, have to meet criteria settled by agencies. Only if the certifiers succeed in revealing critical aspects and opportunistic behavior, quality assurance concepts will be able to build up the reputation necessary to serve as a reliable quality signal (Jahn, Schramm \& Spiller, 2005).

Depending on how much information about the safety of the goods is available to consumers, goods are classified into three categories. First, there are search goods. The consumer is able to obtain information about product safety through inspection - consumers have nearly perfect information. The second category relates to experience goods. Consumers can obtain safety information through repeated purchases or through the reputation 
established by others. The third is credence goods. In this case, consumers cannot discern information on product safety, even after repeated purchases (Antle, 2001). Marette, Crespi \& Schiavina (1999) observe that agricultural markets are working imperfectly due to asymmetric information, since the consumers lack perfect information about product quality.

Jahn, Schramm \& Spiller (2004a) seek to investigate the audit quality of certification systems within the food sector, based on financial auditing. They assume that suppliers are not interested in the highest possible standard of inspection, but in acquiring a certificate as easily as possible. Since the risk of free rider behavior occurs, a strict inspection lowers the probability of successful certification. Therefore, suppliers have an incentive to select an auditor known to employ low inspection standards. Thus, certification systems offer a variety of incentives for inadequate inspections. The conclusion highlights that standards tend to be weak without public regulated inspections. The authors also mention the factors that influence the audit quality: effects on reputation (if there is no reputation, suppliers search for a certifier with low control efforts and inspection prices); protection of quasi-rents (the dependence upon certification is diminished); intensified liability (the quality of the certifier's inspection increases); and improvement of inspection technology (certifiers can have varying levels of success with the same costs due to having different levels of know-how).

Deaton (2004) points out that third-party certifiers play an important role in the global food system. Third-party certifiers are external institutions that assess, evaluate, and certify quality claims. The framework used by Deaton highlights five concepts: uncertainty; information asymmetries; opportunistic behavior; divergences between private and social returns; and signaling institutions. The benefits of third-party institutions result from their capacity to provide market signals. Indeed, the costs of receiving independent thirdparty certification are inversely related to a firm's product quality.

\subsection{Description of certification schemes applied in Brazil Integrated Fruit Production (PIF)}

Integrated Fruit Production was first implemented in Europe in 1970, aiming to reduce the level of pesticides used in fruit production. Argentina, South Africa, New Zealand, the US, and Chile adopted the program in 1993, 
1994, 1996, and 1998, respectively (Associação Gaúcha dos Produtores de Maçã - Gaucho Apple Producers Association - Agapomi, 2005). In Brazil, the Integrated Fruit Production (PIF) scheme started with apple production in the cities of Vacaria-RS, and Fraiburgo-SC, in 1998. The producers' concern was that, without an adequate certification program, they would certainly be out of the international market. Furthermore, other regions in the country started to implement the program supported by the Ministry of Agriculture, Food Supply, and Livestock (Mapa) - (Agapomi, 2005).

PIF is a program created in Brazil by the Normative n. 20 in 2002. The Normatives n. 11 (2003) and n. 12 (2003) establish the requirements for grape and mango production, respectively. In 2006, the Normative n. 58 instituted the control of agro-toxic residues in fruits designated to the European Union, in compliance with the Mapa and the National Plan for the Security and Quality of Products of Vegetable Origin (PNSQV). The purpose of this institution is to guarantee the quality and safety of fruits, as well as an environmentally friendly production.

Regardless of the fruit type, many requirements must be met by the producers to acquire the certificate. The level of compliance to these requirements is divided in mandatory, recommended, forbidden, and allowed with restrictions. Data was compiled considering each sub-thematic area within the major thematic area as one requirement having a different level of compliance. There are a total of 115 requirements, of which mandatory thematic areas and recommended ones represent each about 37\%. The forbidden sub-thematic areas comprise $16 \%$ of all requirements, while the allowed with restrictions ones represent the remaining $10 \%$.

However, differentiating between the three stages - (a) crop management, (b) harvest and post-harvest, and (c) the remaining areas — , it was found that the crop management stage represents almost $50 \%$ of total requirements, followed by harvest and post-harvest with 35\%, and, finally, nearly $15 \%$ for the remaining topic (figure 1). Farmers are provided with technical training regarding Good Agricultural Practices (GAP), including all stages of the crop development, all the way up to the post-harvest process.

For PIF certification, book keeping records are required for inspections. The book keeping process along the production chain is well-defined, including three stages. While book keeping 1 includes more general informa- 
Figure 1: Summary of the PIF requirements

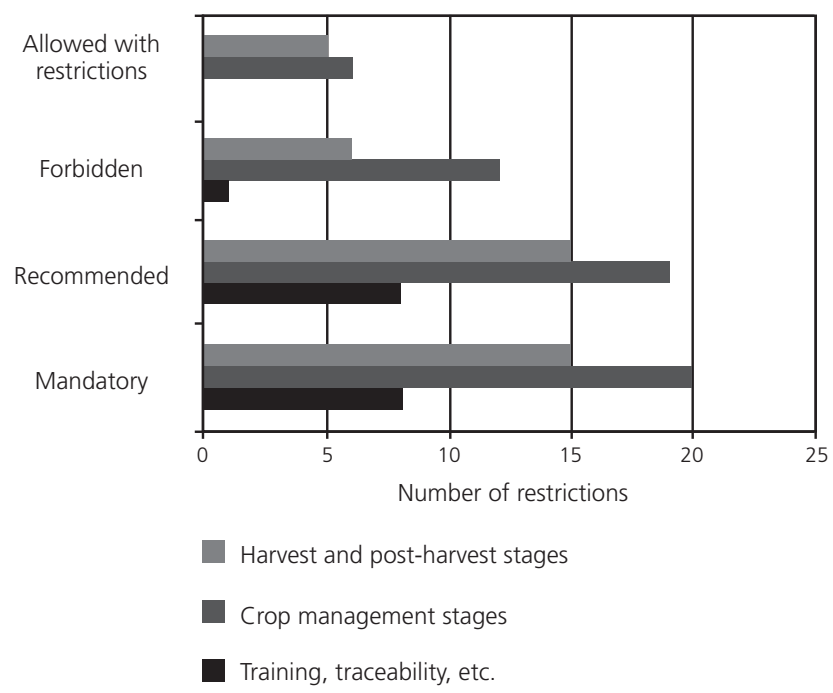

Source: Normative n. 11 and n. 12 (2003).

tion, climate conditions, and machinery, field book keeping 2 contains data with respect to each plot of the productive area. In this section, the producers have to control for possible diseases, plagues, and natural enemies which may occur during the different stages of growth. Data regarding crop management, fertilizers, agrochemicals, irrigation, and crop protection is also required in detail. The post-harvest book keeping is related to data about the identification of the fruit, as well as an analysis of defective fruits. Furthermore, producers have to fill in forms regarding the packaged fruit, the control of sample quality, the hygienic control of the packaging house, and the calibration control of the equipment.

Andrigueto (2002, p. 42) describes the standard procedure when an individual or entity decides to become part of the Integrated Fruit Production system. Roughly, they must go through a waiting period necessary for compliance with the provisions and requirements (Normative n. 20) by the PIF system, according to the individual fruit species, as published by the Ministry of Agriculture, Livestock, and Food Supply. The waiting period corresponds to one agricultural cycle. Conformity to the PIF certificate is obtained in six stages: regularization; request; auditing; decision; acquiring the certificate; and maintenance. 


\section{GlobalGAP}

GlobalGAP started in 1997 as an initiative by retailers belonging to the EuroRetailer Produce Working Group (Eurep). It has subsequently evolved into an equal partnership formed by agricultural producers and their retail customers. Their aim was to develop widely accepted standards and procedures for the global certification of Good Agricultural Practices (GAP) (GlobalGAP, 2007b).

GlobalGAP is a private sector body that sets voluntary standards for the certification of agricultural products. The standard is primarily designed to reassure consumers of the way food is produced at the farm by minimizing the detrimental environmental impact of farming operations, reducing the use of chemical inputs and ensuring a responsible approach to workers' health and safety, as well as animal welfare (GlobalGAP, 2007b).

The characteristics of GlobalGAP can be summarized as: (a) a pre-farmgate standard, which means that the certificate covers the processing of the certified product, beginning with farm inputs like feeding or seedlings, and continuing with all the farming activities, all the way until the product leaves the farm; (b) annual inspections of the producers, as well as additional unannounced inspections; and (c) a set of normative documents. These documents cover the general regulations, the Points of Control and Compliance Criteria, and the checklist (GlobalGAP, 2007b).

Even though the organization possesses an updated version from July 2007, the analysis considers the former version, Version 2.1, from October 2004, which was valid during the data collection of this survey. There are three types of points of control within the GlobalGAP program that producers need to meet in order to obtain the GlobalGAP recognition: "major musts," "minor musts" and "recommendations." In regard to "major musts," a $100 \%$ compliance is required, while for "minor musts," the requirement is 95\%. "Recommendations" do not require a minimum percentage.

In all, there are 214 control points and compliance criteria for the GlobalGAP certificate. They are categorized as: major musts, which represent $23 \%$, minor musts $(46 \%)$, and recommended (31\%). Within the highlighted compliance points classified as major musts are crop protection, with $31 \%$, and production handling, with $24 \%$. The item crop protection is also a control target in the minor musts category, with $43 \%$, followed by fertilizer use, 
with $15 \%$, and, finally, produce production handling and worker health, safety and welfare, with $14 \%$ each. Recommendations emphasize fertilizer use, with $23 \%$, compliance points, worker health, safety and welfare, with $14 \%$, and environmental issues, with $12 \%$.

The same requirements cited above were grouped into three sets: the first one refers to all stages related to crop management (soil, fertilizer, varieties, etc.); the second includes after harvesting and production handling, and the third comprehends the remaining points, such as traceability, environmental issues, book keeping, worker health, safety and welfare. According to the compilation, nearly $60 \%$ of the three categories of compliance relate to the crop management; within this, minor musts requirements sum $46 \%$ of the total, $31 \%$ are recommendations, and, finally, $30 \%$ are major musts (figure 2).

GlobalGAP (2007b) highlights that the standard requirements have to be applied equally around the world. Due to structural reasons, small-scale farmers often face more difficulties to meet the requirements than medium and large producers. As a result, small-scale farmers are at risk of missing out on market access. GlobalGAP has, therefore, implemented a group cer-

Figure 2: Summary of GlobalGAP requirements

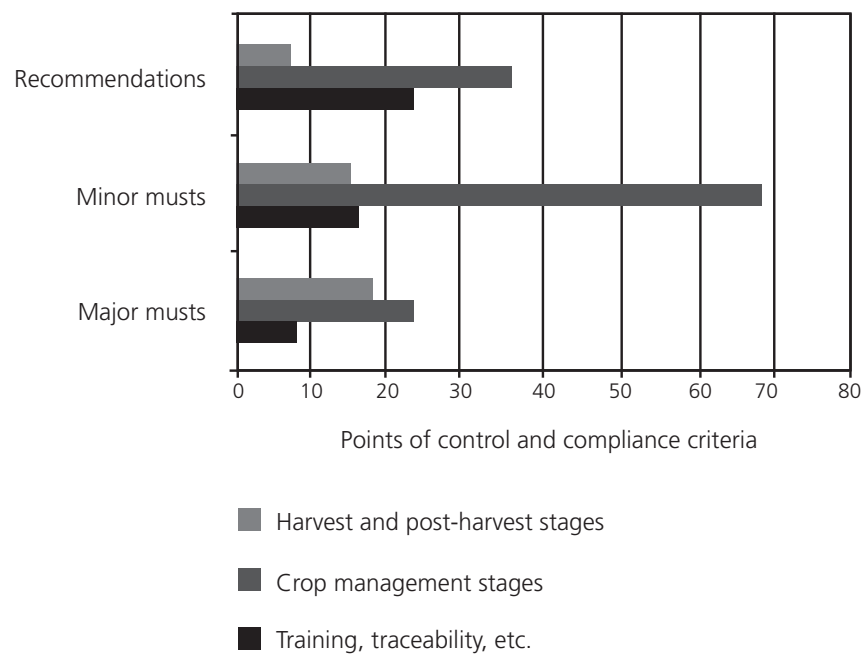

Source: Own compilation based on EurepGAP checklist (2004). 
tification to facilitate market access for small-scale farmers. Group certification implies that smallholders form a group and obtain a certification together. It allows farmers to significantly reduce certification costs, such as inspection charges and overhead costs. In addition, since many requirements necessary for GlobalGAP certification can be centralized (e.g. pesticide controls), farmer groups can benefit from the scale effects. Group structures are also an easier way to provide farmers with advice regarding the implementation of standards. Monitoring is done twice a year. The farmer is aware of the time of the first visit, while the second one takes place without previous notice. The certificate is valid for 12 months.

\section{Fairtrade}

The Fairtrade Labeling Organization (FLO) was created in 1997. It is recognized as a non-profit organization which offers the development of standards that benefit small farmers and their employees, promote sustainable production, and guarantee fair prices, as well as an extra premium. Besides the minimum requirements, the FLO expects that producers continuously improve working conditions, increase environmental sustainability, and also invest in human capital. Furthermore, the FLO provides producers with information regarding new business and market opportunities. Apart from fruits and vegetables, the range of products to which FLO is applied includes tea, coffee, cocoa, honey, juices, wine grapes, dried fruits, nuts, spices, and non-food products, such as flowers and plants, sports balls, and cotton seed (FLO, 2006, p. 3-5).

According to the FLO (2007a), Fairtrade requires fair and transparent trading conditions concerning prices, payment, and quality procedures. The standards require that all products sold with the Fairtrade label must be produced by certified producers. Concerning prices and price premiums, buyers must pay the producers' organizations at least the minimum Fairtrade price set by the FLO. Producers and buyers should have a contract establishing volume, quality, price, and payment conditions. The payment requirement is that, for example, $50 \%$ of the total price should be paid at the moment the product is delivered, and the remainder should follow 48 hours after delivery. 
According to the FLO (2007) the total number of requirements is $105-$ 55 being considered as "Minimum requirements" (52\%), and 50 as "progress" (48\%). "Minimum requirements" must be achieved by all producers, while with respect to "progress requirements," permanent improvement must be visible, as documented through a yearly report by the producers' organizations. The FLO tries to ensure that fair trade benefits are reaching small farmers and small producers' organizations which have potential for development.

In addition, the FLO requires that these organizations should always follow the national legislation, and, in cases where standards are higher than those issued by the FLO, the former ones should prevail. The standards applied to small producers' organizations are divided into four sections: social development, economic development, environmental development, and standards on labor conditions.

The first section considers social aspects such as democracy, participation, transparency, and non-discrimination, among others. In the economic development section, the concerns are about premiums, the ability to export, and organizational improvements. The environmental section focuses on assessment, planning, and monitoring based on an environmental plan, with each producer being responsible for ensuring his compliance. Thus, maintenance of protected areas, sustainability of native species, and the improvement of environmental and agricultural practices should be planned and reported. These concerns are extended to the conservation of fauna and flora, as well as to water management issues. The details about the use and non-use of agrochemicals are well defined. Recycling materials, fire, soil management and non-use of Genetically Modified Organisms (GMO) deserve some attention in the analysis. The last section sets the standards on labor conditions, according to the International Labor Organization (ILO) Conventions. An overview of the four sections is presented in figure 3. There is higher emphasis on environmental development issues (45\% of minimum requirements and $44 \%$ of progress requirements), and standards on labor conditions ( $22 \%$ and $34 \%$, respectively).

Fairtrade certification is accomplished by an international certification company, the FLO-CERT GMBH, in more than 70 countries (FLO, 2006; 
Figure 3: Summary of fairtrade requirements

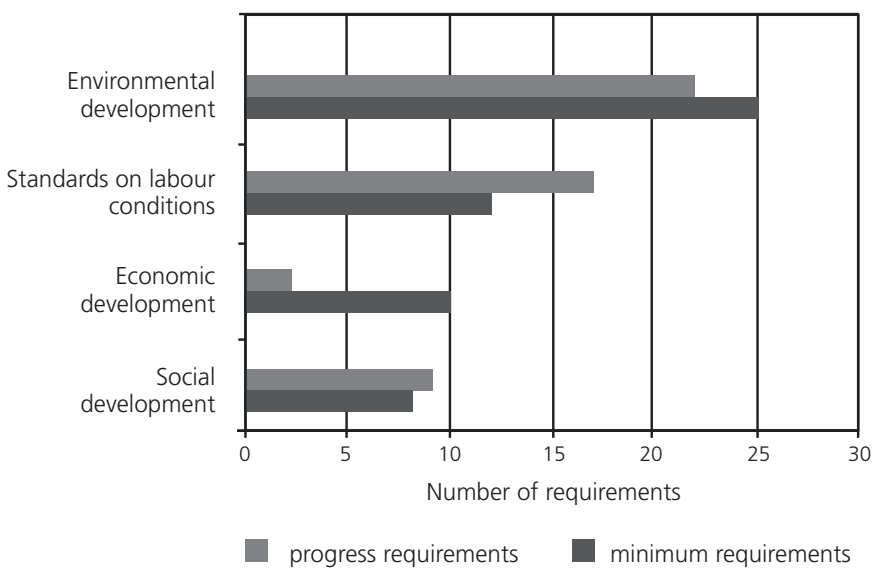

Source: Own compilation based on the FLO (2007)

Flo-cert, 2007). The necessary steps for certification can be divided into: application, initial inspection, evaluation, acquiring certification, and after certification.

The application process begins with filling the application form. The purpose is to provide some information and clarify the rules of the FLO. Afterwards, an inspection takes place in order to evaluate the producer's or trader's compliance with the relevant Fairtrade standards. Next, the correction of earlier non-conformities is evaluated. Once all of them are fixed, the organization issues a one-year certificate. Before the end of a certification cycle, a renewal inspection is done in order to verify compliance with the standards.

\subsection{Third country standards affecting Brazilian fruits exports}

Apart from certification, selected food standards and regulations from other countries affect Brazilian fruits exports. The following section presents a description of regulations from the European Union and the United States, the two major export markets of Brazilian fruits.

Access to markets in the European Union depends on meeting a variety of regulations. The extent of these regulations and their complexity has increased significantly in the last decade. The European Union fruit standards were first regulated in 1972. Regulation (EEC) 1035/72 specifies the size, 
color, caliber, and other quality requirements for fruits and vegetables. In 1990, Council Directive (EEC) 90/642 determined the maximum residue levels (MRL) of pesticide products and its requirements for traceability to this sector.

Furthermore, Regulation (EC) 466/2001 sets the maximum levels for certain contaminants in foodstuffs. In 2004, Regulation (EC) 852/2004 presented the general hygiene rules for foodstuffs, including procedures for verification and compliance. The main objective is to ensure a high level of consumer protection with regard to food safety along the chain. In 2005, Regulation (EC) 2073/2005 on microbiological criteria for foodstuffs included precautionary measures. Additionally, Regulation (EC) 396/2005 established new maximum residue levels of pesticides in foods, as well as products of plant and animal origin. Regulation (EC) 178/2002 sets the general principles and requirements of food laws in the EU related to all stages of production, processing, and distribution (complemented by Regulation $882 / 2004$ ). Many regulations have also been specifically created for fruits and vegetables. Regarding watermelons e.g., Regulation (EC) 1862/2004 sets the respective marketing standards, while Regulation (EC) 2789/1999 sets them for grapes.

Regulation EC (834/2007) establishes a set of objectives, principles, and basic rules for organic production, as well as a permanent importing regime and consistent controlling for organic products. For instance, food will be able to carry the EU organic logo only if at least 95\% of the ingredients are organic. The FAO (2001) highlights that organic fruits and vegetables exported to the European Community, Japan or the United States must meet import requirements relating to size, grade, quality, and maturity. A certificate based on an inspection must be issued by the country's relevant authority to indicate compliance with standards.

Similarly to the EU, the US also has certain regulations which affect exports of fruits from Brazil. According to the United States Department of Agriculture (USDA), quality standards are based on measurable attributes that describe the value of the product. Standards for each product describe the entire range of quality requirements for a product, and the number of grades varies by commodity. For example, the USDA defines the standards related to grading, level and application of pesticides, maturity requirements, and packaging for table grapes and mangoes (USDA, 2007). 


\section{DATA AND METHODS}

A survey of 303 farmers was conducted between July and October 2006 in the São Francisco Valley, on the surroundings of Petrolina (state of Pernambuco) and Juazeiro (state of Bahia), in Brazil. A two-stage stratified sampling technique was applied, as outlined by Levy \& Lemeshow (1999). The first stratum included $\operatorname{small}^{2}(<12$ ha), medium $(>13$ and $<49$ ha), and large producers ( $>50$ ha) in both regions. The final step involved the identification of producers with certification, the ones without certification and those in the process of becoming certified. A total of 18 strata were identified (table 1). To ensure that this sample population could yield significant results from econometric analysis, a statistical power analysis was made to determine the sample size, whereby the expected effect size - i.e. expected differences of means of two populations or the alternative hypothesis - can be detected with a certain power and at a significant level. This approach requires information on population means $(\mu)$ and standard deviation $(\sigma)$ based on lists of producers. The sample size of each stratum was calculated using the Russlenth program. ${ }^{3}$

Table 2 presents the figures of mango and grape farmers in the surveyed regions. Considering both regions, $68 \%$ of the farmers produce mangoes, while $26 \%$ of them concentrate on grape production, while $5 \%$ of the farmers produce both fruits.

Table 1: Population and sample sizes of producers in Juazeiro and Petrolina

\begin{tabular}{|c|c|c|c|c|c|c|c|}
\hline \multicolumn{2}{|c|}{ Type of producer } & \multicolumn{3}{|c|}{ Population } & \multicolumn{3}{|c|}{ Sample size } \\
\hline & & \multirow{2}{*}{$\begin{array}{l}\text { Juazeiro } \\
\text { Farmers }\end{array}$} & \multirow{2}{*}{$\frac{\text { Petrolina }}{\text { Farmers }}$} & \multirow{2}{*}{$\begin{array}{c}\text { Total } \\
\text { population }\end{array}$} & \multicolumn{2}{|l|}{ Jua/Petro } & Total sample \\
\hline \multicolumn{2}{|c|}{ Farm land size Certification } & & & & Farmers & $\%$ & size \\
\hline \multirow[t]{3}{*}{ Small } & Without & 587 & 2,799 & 2,212 & 90 & 39.0 & 120 \\
\hline & In process & 30 & 149 & 119 & 30 & 13.0 & 59 \\
\hline & With & 0 & 91 & 91 & 30 & 13.0 & 30 \\
\hline \multirow[t]{3}{*}{ Medium } & Without & 4 & 58 & 54 & 30 & 13.0 & 34 \\
\hline & In process & 4 & 67 & 63 & 30 & 13.0 & 34 \\
\hline & With & 0 & 20 & 20 & 20 & 8.7 & 20 \\
\hline \multirow[t]{4}{*}{$\underline{\text { Large }}$} & Without & 1 & 1 & 0 & 0 & 0.0 & 1 \\
\hline & In process & 0 & 1 & 1 & 1 & 0.4 & 1 \\
\hline & With & 4 & 24 & 20 & 0 & 0.0 & 4 \\
\hline & Total & 630 & 3,210 & 2,580 & 231 & 100 & 303 \\
\hline
\end{tabular}


Table 2: Population of grape and mango farmers in the region

\begin{tabular}{lcccccc}
\hline & \multicolumn{2}{c}{ Juazeiro } & \multicolumn{2}{c}{ Petrolina } & \multicolumn{2}{c}{ Both municipalities } \\
\hline Type of fruits & Total of farmers & $\%$ & Total of farmers & $\%$ & Total of farmers & $\%$ \\
\hline Mango & 64 & 88.9 & 144 & 62.3 & 208 & 68.6 \\
\hline Grapes & 1 & 1.4 & 78 & 33.8 & 79 & 26.1 \\
\hline Mangoes and grapes & 7 & 9.7 & 9 & 3.9 & 16 & 5.3 \\
\hline Total & 72 & & 231 & & 303 & 100.0 \\
\hline Source: Own compilation & & & & & &
\end{tabular}

\section{DISCUSSIONS AND RESULTS}

\subsection{Certified mango and grape farmers: one versus two certificates}

Data regarding the 54 certified producers is used to analyze producers with only one certificate (57\% or 30 producers) and those having two (43\% or 22 producers). Single certified refers to producers having only one certificate, and double certified refers to those having two. Results are presented in table 3. Two tripled certified farmers are excluded from this analysis.

Table 3: Description of the variables: one certificate versus two certificates

\begin{tabular}{|c|c|c|c|}
\hline \multirow[t]{2}{*}{ Description of the variables } & \multicolumn{2}{|c|}{ Number of certificates } & \multirow{2}{*}{$\begin{array}{c}\mathrm{Chi}^{2}, \mathrm{t} \text { test } \\
\text { Sig. }\end{array}$} \\
\hline & One cert. & Two cert. & \\
\hline Investments on new infrastructure (R\$) (mean value) & 182,249 & 45,356 & $0.062^{*}$ \\
\hline Cost of certification ( $R \$$ ) (mean value) & 1,213 & 2,403 & $0.003 * * *$ \\
\hline \multicolumn{4}{|l|}{ Grapes (mean value) } \\
\hline Productivity (tons/ha) & 24.6 & 19.9 & 0.165 \\
\hline Production cost $(\mathrm{R} \$ / \mathrm{kg})$ & 0.92 & 1.25 & 0.129 \\
\hline Total production cost ( $\mathrm{R} \$ / \mathrm{ha})$ & 22,929 & 22,462 & 0.895 \\
\hline Total income ( $\mathrm{R} \$ / \mathrm{ha})$ & 43,052 & 42,198 & 0.920 \\
\hline Net income $(\mathrm{R} \$ / \mathrm{ha})$ & 20,623 & 19,236 & 0.629 \\
\hline Price received before certifying $(R \$ / \mathrm{kg})$ & 1.75 & 2.09 & 0.425 \\
\hline Price received after certifying $(\mathrm{R} \$ / \mathrm{kg})$ & 2.23 & 2.70 & 0.240 \\
\hline \multicolumn{4}{|l|}{ Mangoes (mean value) } \\
\hline Productivity (tons/ha) & 29.3 & 23.5 & 0.112 \\
\hline Production cost $(\mathrm{R} \$ / \mathrm{kg})$ & 0.44 & 0.47 & 0.302 \\
\hline Total production cost ( $\mathrm{R} \$ / \mathrm{ha})$ & 13,045 & 10,945 & 0.210 \\
\hline Total income ( $R \$ / h a)$ & 24,104 & 20,328 & 0.426 \\
\hline Net income $(R \$ / h a)$ & 11,058 & 9,392 & 0.920 \\
\hline Price received before certifying $(R \$ / \mathrm{kg})$ & 0.82 & 0.84 & 0.890 \\
\hline Price received after certifying $(\mathrm{R} \$ / \mathrm{kg})$ & 1.32 & 1.30 & 0.923 \\
\hline \multicolumn{4}{|l|}{ One certification scheme [PIF $n=5$, GlobalGAP $n=21$, Faitrade $n=4$ ] } \\
\hline \multicolumn{4}{|l|}{ and double certification squeme [PIF\&Global n = 8, PIF\&Fair $n=14$ ] } \\
\hline \multicolumn{4}{|l|}{ *** Significant at $1 \%$ level, ** at $5 \%$ level and *at $10 \%$ level } \\
\hline Source: Own compilation & & & \\
\hline
\end{tabular}


Surprisingly, single-certified mango and grape farmers harvested more tons per ha than farmers with two certificates. Therefore, the total production cost per $\mathrm{kg}$ of grapes and mangoes is higher for double-certified than for single-certified producers. As a result, single-certified farmers also receive higher net income per ha compared to double-certified ones. This is true for mangoes as well as for grapes. However, the price received per $\mathrm{kg}$ by single- and double-certified farmers differs by fruit. For grapes, the price before and after is lower for single-certified farmers than for double-certified ones; such a difference does not exist for mangoes. In terms of percentage, single-certified farmers received a $61 \%$ higher price for mangoes, compared to $55 \%$ for double-certified ones. Before adopting one certificate, grape farmers made $\mathrm{R} \$ 1.75$, while those with two certificates made $\mathrm{R} \$ 2.09$. After adopting certification, single-certified farmers made R\$2.23, while double-certified ones made $\mathrm{R} \$ 2.70$. An increase of $27 \%$ and $29 \%$ is found, respectively.

Sebrae is considered by all farmers a very important organization in supporting certification, while Embrapa was indicated mainly by singlecertified farmers. Approximately $90 \%$ of the farmers mention obtaining knowledge from Embrapa. In addition, Sebrae is considered by $96 \%$ of the farmers as the source where they obtain knowledge and updates through training courses. Another potential source of information and updates is the farmers' social network.

Further, single-certified farmers have invested significantly higher amounts on new infrastructure for their farms. Nevertheless, farmers with two certificates spend $\mathrm{R} \$ 2,403$ yearly on certification (including monitoring and renewal costs). Single-certified farmers spend half of this amount (R\$ 1,213).

In the surveyed region, farmers started to adopt certification in 2003 and 2004. There is no significant difference between the time of adoption and the type of schemes. However, the adoption of a certain certification scheme influences the farmer's decision as to whether to continue to trade with the current buyer or to shift. Table 4 compares the number of years that farmers have obtained certification [a] and the number of years that they have been selling to a specific buyer [b]. This analysis may indicate whether certification plays a positive role in changing the buyer. 
Table 4: Comparison between the years the producer has been certified [a] and the year he started to sell to a specific buyer [b]

\begin{tabular}{lccc}
\hline Number of certificates & \multicolumn{3}{c}{ Comparing [a] and [b] } \\
\cline { 2 - 4 } & $\mathrm{a}>\mathrm{b}$ & $\mathrm{a}<\mathrm{b}$ & $\mathrm{a}=\mathrm{b}$ \\
\hline One certificate (in \%) & 6.7 & 73.3 & 20.0 \\
\hline Two certificates (in \%) & 0.0 & 95.8 & 4.2 \\
\hline One certification scheme [ $=30]$ and double certification squeme [n=22] & & \\
Source: Own compilation & & &
\end{tabular}

(a) If $a>b$, it means that producers did not change buyers after adopting certification;

(b) If $a<b$, it means that producers switched to a new buyer after becoming certified; and

(c) If $\mathrm{a}=\mathrm{b}$, it means that producers changed to a new buyer in the same year certification was attained.

It was found that $73 \%$ and $96 \%$ of producers with one and two certificates, respectively, change the type of buyer after obtaining certification. Generally, this means that the producer changes from an individual buyer to a group or cooperative. Twenty percent of single-certified producers and only $4 \%$ of double-certified ones highlight the fact that they have changed the type of buyer in the same period of adoption. Finally, for $6 \%$ of the farmers with one certificate, the adoption of certification does not play an important role in changing the type of buyer.

\subsection{Comparative analysis by certification scheme}

The following analysis focuses on the selected certification schemes adopted by certified mango and grape farmers. It looks closely to the major economic differences among each certification scheme, as well as to their combinations. As table 5 shows, results are omitted in some cases where the sample is not representative. Farmers having PIF and GlobalGAP are denominated by PIF\&Global, and those having PIF and Fairtrade, by PIF\&Fair.

PIF\&Global certified farmers possess more irrigated areas (64 ha), followed by those with GlobalGAP ( $33 \mathrm{ha}$ ), compared to the small irrigated areas owned by the remaining groups. Data on the productivity reveals that farmers with GlobalGAP have higher productivity for both fruits. In order to comply with requirements, farmers need to invest in infrastructure for 
Table 5: Comparing certification schemes

\begin{tabular}{|c|c|c|c|c|c|c|}
\hline \multirow[t]{2}{*}{ Description of variables } & \multicolumn{3}{|c|}{ Type of certification scheme } & & & \multirow{2}{*}{$\begin{array}{c}\mathrm{Chi}^{2}, \mathrm{t} \text { test } \\
\text { Sig. }\end{array}$} \\
\hline & PIF & GlobalGAP & \multirow{2}{*}{$\begin{array}{c}\text { Fairtrade } \\
4.2 \\
\end{array}$} & PIF\&Global & \multirow{2}{*}{$\frac{\text { PIF\&Fair }}{2.30 .011^{* *}}$} & \\
\hline Irrigated area (mean values in ha) & 6.3 & 33.0 & & 64.4 & & \\
\hline Investments in new infrastructure (R\$) & 54,660 & 244,471 & 15,065 & 136,062 & 0.0 & 0.479 \\
\hline Cost of certificate maintenance $(\mathrm{R} \$)$ & 315 & 1,637 & 108 & 6,998 & 106 & $0.000 * * *$ \\
\hline \multicolumn{7}{|l|}{ Grapes (mean value) } \\
\hline Productivity of grapes (tons/ha) & \multicolumn{2}{|l|}{18.1} & - & 15.9 & - & $0.000 * * *$ \\
\hline Production costs $(\mathrm{R} \$ / \mathrm{kg})$ & \multicolumn{2}{|c|}{0.86} & - & 1.31 & - & 0.723 \\
\hline Total production costs ( $R \$ / h a)$ & 15,566 & 24,448 & - & 19,996 & - & 0.159 \\
\hline Total income ( $R \$ / h a)$ & 30,716 & 47,252 & - & 41,285 & - & 0.830 \\
\hline Net income ( $R \$ / h a)$ & 15,150 & 22,803 & - & 21,289 & - & 0.871 \\
\hline Price received before certifying $(R \$ / \mathrm{kg})$ & \multicolumn{2}{|c|}{1.7} & - & 2.4 & - & 0.329 \\
\hline Price received after certifying $(\mathrm{R} \$ / \mathrm{kg})$ & \multicolumn{2}{|c|}{2.0} & - & 2.9 & - & 0.603 \\
\hline \multicolumn{7}{|l|}{ Mangoes (mean value) } \\
\hline Productivity (tons/ha) & - & 33.0 & 25.2 & - & 22.5 & 0.104 \\
\hline Production costs $(\mathrm{R} \$ / \mathrm{kg})$ & - & 0.44 & 0.47 & - & 0.46 & 0.246 \\
\hline Total production costs $(\mathrm{R} \$ / \mathrm{ha})$ & \multicolumn{2}{|c|}{$-\quad 14,584$} & 11,733 & \multicolumn{2}{|c|}{$-10,285$} & 0.154 \\
\hline Net income ( $R \$ / h a)$ & \multicolumn{2}{|r|}{20,626} & 17,744 & \multicolumn{2}{|c|}{$-16,065$} & $0.004 * * *$ \\
\hline Price received before certifying $(R \$ / k g)$ & - & 0.9 & 0.7 & - & 0.7 & 0.536 \\
\hline Price received after certifying $(\mathrm{R} \$ / \mathrm{kg})$ & - & 1.4 & 1.1 & - & 1.1 & 0.269 \\
\hline
\end{tabular}

their farms. The findings clearly indicate GlobalGAP certified farmers as those who invested the highest amount in new infrastructure ( $\mathrm{R} \$ 245,000)$. PIF\&Global certified farmers invested approximatly R $\$ 136,000$. The investments done by the others are considerably smaller.

With respect to the production costs per kg of mangoes, very similar results are found for single and double-certified farmers. Thus, the total production costs, total income, and net income are higher for GlobalGAP certified farmers, if compared to the other farmers. However, GlobalGAP certified mango farmers received the highest net income. PIF\&Global certified mango farmers are not far behind with regard to their net income. Besides, PIF\&Global certified farmers pay certification costs of $\mathrm{R} \$ 7,000$ for both certificates, while GlobalGAP paid around R\$ 1,700. Fairtrade and PIF\&Fair farmers are only responsible for a share of the costs, since the association takes over the responsibility. PIF farmers, for instance, received subsidies from Sebrae. 
A comparison between prices received before and after certifying shows that PIF\&Global and GlobalGAP certified grape farmers received a price increase of $\mathrm{R} \$ 0.50$ per $\mathrm{kg}$, while PIF got only a $\mathrm{R} \$ 0.30$ increase. However, in terms of percentage, GlobalGAP certified farmers received an increase of $27 \%$ in price, while PIF\&Global got $20 \%$, and PIF farmers got $17 \%$. With respect to mango farmers, the difference between prices received before and after adopting certification was R\$ 0.40 per kg. GlobalGAP certified farmers and Fairtrade ones indeed received a price increase of 57\%.

A discussion by Espanion et al. (2005)mentioned benchmarking between GlobalGAP and PIF systems for fruits and vegetables in Brazil. The authors pointed out some equivalences between PIF and GlobalGAP, such as food safety guarantee, traceability, and the use of pesticides registered in the exporting or importing country, as well as worker safety. While PIF shows details for each product, such as fruit color, size, sugar levels, $\mathrm{pH}$, texture, etc., GlobalGAP represents generic requirements for fruits and vegetables, meats, seeds, etc. An attempt to benchmark by the Ministry of Agriculture, Livestock, and Food Supply is still ongoing.

Nevertheless, besides the effort of the Brazilian government in developing and implementing a national certification scheme, acceptance at both the national and international levels was below expectations. Indeed, as Vitti \& Cintra (2003) highlight, at the end of 2003, supermarkets in the European Union started to require the Global Partnership for Good Agricultural Practice (GlobalGAP) certification from Brazilian fruit exporters, instead of PIF.

\subsection{Comparative analysis of different mango and grape size farms}

This section aims to verify the main differences and similarities between economic variables among small and medium-sized farms that belong to one of these three groups: certified, in process, and non-certified. Table 6 shows the data regarding type of certification schemes adopted by different sized producers. Analyzing the figures from the producers' size perspective, they reveal that $70 \%$ of certified producers are small, while $30 \%$ of them are medium. Small farms have less than 13 ha, while medium ones have 13 ha or more. Six cases of large-sized farmers were excluded from this analysis. Hirsch (2005) points out that the Juazeiro/Petrolina region is basically comprised of small farmers. They represent about $70 \%$ of all farmers in the re- 
Table 6: Small and medium-sized farms

\begin{tabular}{lccccccc}
\hline \multirow{2}{*}{ Type of producers } & \multicolumn{3}{c}{ Farm size } & \\
\cline { 2 - 7 } & \multicolumn{3}{c}{ Small } & & Medium & \\
\hline & \multicolumn{2}{c}{ Total } & $\%$ & Total & $\%$ & Total & $\%$ \\
\hline Non-certified farmers & 120 & 40.4 & 34 & 11.3 & 154 & 51.9 \\
\hline In process of obtaining certification & 59 & 19.9 & 34 & 11.4 & 93 & 30.3 \\
\hline Certified farmers & 30 & 10.1 & 20 & 6.7 & 50 & 16.8 \\
\hline Total & 209 & 70.4 & 88 & 29.6 & 297 & 100 \\
\hline Source: Own compilation & & & & & &
\end{tabular}

gion, yet they own only $17 \%$ of the cultivated area. The remaining $30 \%$ is split between medium and large growers.

Productivity of medium-sized certified and in process of obtaining certification mango farmers is very similar. For the non-certified farmers, productivity is a bit higher in medium-sized farms. Also, results on grape productivity show that medium-sized farmers have the highest productivity, however the difference for certified farmers is much larger than that of uncertified farmers (table 7).

There are major differences with regard to net income between small and medium-sized farmers. Mango medium-sized farms have higher income, compared to small ones. However, small non-certified grape farmers have the highest net income compared to other small-scale farmers, while medium-sized certified ones present the highest net income per ha, compared to medium-sized farmers. An analysis of the production cost per kg reveals that mango farmers present similar figures for small and mediumsized farms. However, for grape farmers the difference is larger. For instance, small and medium-sized certified farmers have a difference in cost per $\mathrm{kg}$ of $\mathrm{R} \$ 0.13$.

Considering that medium-sized farmers have more irrigated area, it is expected that they would have a higher harvested volume. Nevertheless, the total production is definitely dependent on the type of irrigation system used. Results show that medium-sized farms, regardless of their type, have a more sophisticated system (varying between $88 \%$ and 100\%). Thus, $70 \%$ of the small certified ones also have a more sophisticated system.

Prices per $\mathrm{kg}$ of mango received before adopting certification were similar ( $\mathrm{R} \$ 0.70$ and $\mathrm{R} \$ 0.80$ ), while prices per $\mathrm{kg}$ of grapes ranged between 
Table 7: Comparative analysis of land size for all types of farmers

\begin{tabular}{|c|c|c|c|c|c|c|c|}
\hline \multirow[t]{2}{*}{ Description of the variables } & \multicolumn{2}{|c|}{$\begin{array}{l}\text { Non-certified } \\
\text { farmers }\end{array}$} & \multicolumn{2}{|c|}{$\begin{array}{c}\text { Farmers in } \\
\text { process }\end{array}$} & \multicolumn{2}{|c|}{ Certified farmers } & \multirow{2}{*}{$\begin{array}{c}\mathrm{Chi}^{2}, \mathrm{t} \\
\text { test } \\
\text { Sig. }\end{array}$} \\
\hline & $\overline{\text { Small }}$ & Medium & Small & Medium & Small & Medium & \\
\hline \multicolumn{8}{|l|}{ Grapes } \\
\hline Grape productivity (tons/ha) & 15.4 & 16.3 & 16.1 & 19.1 & 20.7 & 27.1 & $0.004^{* * *}$ \\
\hline Production costs $(\mathrm{R} \$ / \mathrm{kg})$ & 0.93 & 0.83 & 0.81 & 0.89 & 0.92 & 0.85 & $0.000 * * *$ \\
\hline \multicolumn{8}{|l|}{ Total production costs } \\
\hline Total income (R\$/ha) & 26,059 & 28,703 & 24,254 & 35,949 & 30,548 & 48,024 & $0.002 * * *$ \\
\hline Net income (R\$/ha) & 9,765 & 15,433 & 10,154 & 19,326 & 11,415 & 24,771 & $0.000 * * *$ \\
\hline \multicolumn{8}{|l|}{ Price received before } \\
\hline $\begin{array}{l}\text { Price received after } \\
\text { certifying }(\mathrm{R} \$ / \mathrm{kg})\end{array}$ & \multicolumn{2}{|c|}{ Price received after } & - & - & 1.94 & 2.23 & - \\
\hline \multicolumn{8}{|l|}{ Mangoes } \\
\hline $\begin{array}{l}\text { Mango productivity } \\
\text { (tons/ha) }\end{array}$ & 18.4 & 21.9 & 20.9 & 19.8 & 23.2 & 23.6 & $0.001 * * *$ \\
\hline Production costs $(\mathrm{R} \$ / \mathrm{kg})$ & 0.40 & 0.42 & 0.35 & 0.38 & 0.45 & 0.42 & $0.000^{* * *}$ \\
\hline \multicolumn{8}{|l|}{ Total production costs } \\
\hline Total income (R\$/ha) & 16,158 & 18,317 & 15,118 & 19,165 & 16,636 & 26,450 & 0.158 \\
\hline Net income (R\$/ha) & 8,656 & 9,833 & 7,705 & 10,561 & 6,196 & 12,288 & $0.000 * * *$ \\
\hline $\begin{array}{l}\text { Price received before } \\
\text { certifying }(R \$ / \mathrm{kg})\end{array}$ & 0.8 & 0.8 & 0.7 & 0.8 & 0.7 & 0.8 & 0.734 \\
\hline \multicolumn{8}{|l|}{ Price received after } \\
\hline \multicolumn{8}{|c|}{ Non-certified farmers [ $n=154]$, in process [ $n=93]$, and certified $[n=50]$} \\
\hline \multicolumn{8}{|c|}{ *** Statistically significant at $1 \%$ level; ${ }^{* *}$ at $5 \%$ level; * at $10 \%$ level } \\
\hline Source: Own compilation & & & & & & & \\
\hline
\end{tabular}

$\mathrm{R} \$ 1.40$ and $\mathrm{R} \$ 1.90$. Small-sized grape farmers received a 38\% higher price after certifying, while medium-sized ones had a $27 \%$ increase. In the case of mangoes, small producers received a $62 \%$ increase and medium ones obtained a $47 \%$ higher price due to certification.

All farmers were informed about certification through Sebrae and Embrapa. Cooperatives, groups, and associations do not play an important role as primary sources of information. This indicates that these organizations, are interested in having more farmers become members. Although certified farmers are usually members of one of these organizations, they certainly obtain information on certification and updates only after they became members. Furthermore, Sebrae is indicated by small and medium-sized 
farmers as a very important organization supporting certification schemes. Embrapa is considered very important mainly by medium-sized farmers.

Hirsch (2005) points out that the presence of Embrapa in the São Francisco Valley is fundamental to the sustainable development of the region because of the need to diversify production, with the potential growth of planted areas and irrigation infrastructure. Thus, according to the survey results, Sebrae offers training courses which are attended by almost all farmers. It is interesting to note that all certified farmers mentioned benefiting from both research and training courses offered by Embrapa and Sebrae, respectively.

More specifically, in 1999, the environmental branch of Embrapa, in cooperation with Embrapa Semi-Arid, Valexport, the Irrigated District of Nilo Coelho, and other national and international organizations, elaborated an environmental program for the São Francisco Valley, called "Irrigated fruit culture environmental quality in the Brazilian Northeast - Ecofrutas.” This program was the starting point for the implementation of the PIF certification of grapes and mangoes in the region. In the experimental stage, 14 grape and mango exporting companies were selected to participate in the program. The first stage was financially supported by Valexport [with resources obtained by The National Fruit Culture Developing Program]. The second stage, however, was, financially supported by the Mapa and the National Council for Scientific and Technological Development (CNPq), not only to support the production of grapes and mangoes, but also of apples, peaches, bananas, and citrus fruits (Embrapa Cpatsa, 2006).

Later, in 2004, Sebrae and the National Institute of Metrology, Standardization and Industrial Quality (Inmetro) ${ }_{4}$ settled an agreement which aims at promoting the sustainable inclusion of small and medium-sized enterprises or farmers in the market, in order to stimulate their economic and social development. This is expected to be achieved by providing technical support to the producers through weekly visits, and thus enable them to obtain PIF and GlobalGAP certifications. In addition, financial support was given by Sebrae covering $50 \%$ of the certification cost, with the remaining $50 \%$ of the cost having to be paid back by the farmer. According to the agreement, the financial support amounts to $€ 5,550$ per farmer. This amount should be paid back in three years in the form of monthly installments (Agenda Sebrae de Notícias, 2005). 
Since 1999, Sebrae has invested $€ 370,400$ in research for the development of new varieties of seedless grapes on approximately 4,000 ha in the region, as covered by the Fruit Culture Program. The project was supported by Embrapa and the Valexport. Overall, the Fruit Culture Program supported by Sebrae is based on three pillars: technology, management, and trading. The target is to make small farmers competitive on both national and international levels by providing them with seminars, field visits, and training courses.

\section{CONCLUSION}

The comparative analysis of the certification schemes which exist in the fruit sector in Brazil has shown that GlobalGAP and the Integrated Fruit Production (PIF) are similar certification schemes. However, they differ with respect to the number of requirements and their distribution over various stages (e. g. production, post-harvesting). In addition, PIF certification requires a book keeping system, while GlobalGAP does not. But since GlobalGAP auditors accept the book keeping provided by PIF, farmers aiming to adopt GlobalGAP face an easier process when they already have PIF. Contrary to PIF and GlobalGAP, Fairtrade certification concentrates on producers' organizations and cooperatives of small-scale farmers, and not on individual farmers. In addition, a lot of attention is given to labor and environmental conditions, besides the guarantee of a minimum price for farmers.

The main findings based on the certification schemes adopted by certified mango and grape farmers show that GlobalGAP certified ones have higher productivity for both fruits. GlobalGAP certified mango and grape farmers also have more irrigated area and receive the highest net income. PIF\&Global paid the highest cost for certification. GlobalGAP certified mango farmers and Fairtrade ones received an increase of 57\% in prices after adopting certification, while GlobalGAP certified grapes farmers received an increase of $27 \%$.

Furthermore, results show that single-certified mango and grape producers have higher productivity compared to double-certified ones. Notwithstanding, the income of farmers with one certificate is higher than that 
of the remaining group. After adopting certification, single certified mango farmers received $61 \%$ higher price compared to double-certified ones, who received a 55\% increase. Thus, single-certified grape farmers note a price increase of $27 \%$, while double-certified ones receive a $29 \%$ higher price. However, double-certified grape farmers have higher net income, although they have twice the annual cost of certification. After adopting certification, $73 \%$ and $96 \%$ of the single and double-certified producers change buyers in the next harvesting season. The comparative analysis hardly shows any differences between having one or two certificates. The cost of certification is also twice higher for double-certified farmers, compared to single-certified ones.

With respect to the size of the farms, there is a concern that small producers' participation in the international fruit and vegetable trade could be diminishing as a result of the increasing prevalence of certification and standards in the sector. Based on a comparative analysis between small and medium-sized farms, medium-sized mango farmers have higher productivity than smal-sized ones. Hence, medium-sized farms possess more irrigated area and have a more sophisticated irrigation system, and they also achieve a higher income compared to small ones. Nevertheless, this study shows that small mango and grape producers receive a higher price per $\mathrm{kg}$ after certifying compared to medium ones. For instance, small and medium mango farmers receive a $62 \%$ and a $47 \%$ higher price, while small and medium grape ones receive a price increase of $38 \%$ and $27 \%$, respectively. It can be concluded that evidence on marginalization of small farmers is not found in this study. These findings are in line with Chemnitz (2007). The study provides an empirical analysis of the compliance decision behavior and the compliance process of standards related to the Moroccan tomato export sector between certified and non-certified producers. The results suggest that small producers are not particularly disadvantaged in the compliance process.

Reasons motivating farmers to vertically integrate are the reduction in transaction costs resulting from the economies of scale, and the need to ensure consistent quality supply through the adoption of certification. The low number of certified mango and grape farmers in the Petrolina/Juazeiro region, compared to the number of farmers harvesting fruits, indicates that 
the fruit sector has a huge potential for growth and expansion. Targeted support from the government and private sector will likely contribute to an increased competitiveness of the fruit sector.

Based on the findings of this study, certification is considered a catalyst to increased exports, with farmers benefiting in economic and environmental terms. On the one hand, farmers have an incentive to upgrade, and are able to access the international market with certification. Mango and grape producers having a certificate are more likely to find customers in international markets. Thus, certification is indeed a passport to access international markets. Contrary to the arguments of Usaid (2005), the adoption of standards is not accompanied by marginalization and exclusion of farmers from the market, as they impose prohibitively high barriers on certain producers in terms of short-term and long-term efforts needed for production under certification.

On the other hand, certification excludes less capable growers from the market, meaning that the increasing level of requirements per se selects the farmers who are able to comply. Dolan, Humphrey \& Pascal (1999) argue that requirements imposed by supermarkets in the UK act as an effective barrier to participation of small African exporters in the chain.

In addition, access to information may also restrict farmers from participation in certification programs. Kleinwechter \& Grethe (2006) analyzed the adoption of GlobalGAP by mango exporters in Peru, and found that access to information by producers promotes the adoption, influences decision-making, supports producers in the implementation stage, and, finally, excludes producers from GlobalGAP markets. Thus, organizations supported by the government should assure that information is available, and that certification is a transparent and voluntary process. Adopting two certificates does not necessarily pay off, but in some cases it might open the market to specific countries.

\section{NOTES}

1. In WTO terminology, mandatory standards are referred to as technical regulations under the Agreement on Technical Barriers to Trade, and also sanitary or phytosanitary measures, under the Agreement on the Application of Sanitary and Phytosanitary Measures. 
2. Definition of land size according to Sebrae in Petrolina.

3. Available on the website: http://www.cs.uiowa.edu/ rlenth/Power/(Accessed August, 2006)

4. Inmetro was created by law in December, 1973.

\section{REFERENCES}

AGAPOMI. Associação Gaúcha dos Produtores de Maçã. História da produção integrada de frutas. http://www.agapomi.com.br. (Accessed Mar. 2005). 2005.

AGÊNCIA SEBRAE DE NOTÍCIAS. Bônus subsidia custo de certificação em até 50\%. http://www. sebraers.interjornal.com.br/noticia_pdf.kmf?noticia=2809180. (Accessed Jan. 2005). 2005.

ANDRIGUETO, J. R. Legal Marks of Integrated Fruit Production in Brazil. Organized by José Rosalvo Andrigueto and Adilson Reinaldo Kososki. Translated by Adriana Guedes. Brasilia: mapa/SARC, p. 60, 2002.

ANTLE, J. Economic analysis of food safety. In: GARDNER, B.; RAUSSER, G. (Eds.). Handbook of Agricultural Economics, v. 1, part 2, p. 1083-1136, 2001.

BASU, A.; CHAU, N.; GROTE, U. On export rivalry and the greening of agriculture - The role of eco-labels. Agricultural Economics, v. 31, issue 2-3, p. 135-147, 2004.

CASWELL, J. A. E.; BREDAHL, M. E.; HOOKER, N. M. How quality management systems are affecting the food. In: Review of Agricultural Economics, v. 20-22; p. 547-557, 1998.

CHEMNITZ, C. The compliance process of food quality standards on primary producer level: a case study of the EurepGAP standard in the Moroccan tomato sector. Humboldt-University of Berlin. Working Paper 81, p. 31, 2007.

DEATON, B. J. A Theoretical Framework for Examining the Role of Third-party Certifiers. Food Control 15, p. 615-619, 2004.

DIRECTIVE 90/642/EEC. Fixing of maximum levels for pesticide residues in certain products of plant origin, including fruit and vegetables. Official Journal L 350, 14 Dec. 1990, p. 7179. 1990.

DOLAN, C.; HUMPHREY, J.; PASCAL, C. H. Horticulture commodity chains: the impact of the UK market on the African fresh vegetable industry. Working Paper 96. Brighton: Institute of Development Studies. 1999.

EL-TAWIL, A. An In-depth Study of the Problems by the Standardizers and other Stakeholders from Developing Countries - ISO/WTO regional workshops: Part 1, International Organization for Standardization, Geneva. 2002.

EMBRAPA CPATSA. Produção integrada de uvas finas de mesa e produção integrada de Manga: implantação do programa de produção integrada de manga na região do submédio do Vale do São Francisco. http://www.cpatsa.embrapa.br/pif/. (Accessed Jan. 2008). 2006. 
ESPANION, P.; MARIUZZO, D.; ROJAS, J. et al. Country case Brazil: fruits and vegetables. Presented at UNCTAD/Inmetro Sub-regional Stakeholder Meeting on EurepGAP: Opportunities and challenges for Central and South America. Rio de Janeiro, Brazil. 2005.

EUREPGAP CHECKLIST. EurepGAP checklist for fruit and vegetables, version 2.1, Oct. www. globalgap.org. (Accessed Jan. 2008). 2004.

FAO. World markets for organic fruit and vegetables - Opportunities for developing countries in the production and export of organic horticultural products. Rome: ITC, TCARC, p. 312. http://www.fao.org/docrep/004/Y1669E/Y1669E00.HTM. (Accessed Oct. 2007). 2001.

Environmental and Social Standards, Certification and Labeling for Cash Crops. Rome, p. 120, 2003.

FLO. Fairtrade Labeling Organizations International Annual Report 2006/2007: shaping global partnerships. Bonn, Germany. p. 30, 2006.

Generic fairtrade for standards for small farmers organizations. Version August. Bonn, Germany. p. 24, 2007.

_ ; Fairtrade standards for fresh fruit (except bananas) hired labour. Bonn, Germany. 2007a.

FLO-CERT. Certification. Data on steps how to certify. Germany: Bonn. (Accessed Sep. 2007), 2007.

GLOBALGAP. 2007b. Information available on the website http://www.globalgap.org. (Accessed Aug. 2007).

HENSON, S. The role of public and private standards in regulating international food markets. IATRC summer symposium Food regulation and trade: institutional framework, concepts of analysis and empirical evidence. Germany: Bonn, 2006.

.; HOLT, G. Exploring incentives for the adoption of food safety controls: HACCP Implementation in the UK Dairy Sector. Review of Agricultural Economics, v. 22, n. 2, p. 407-420, 2000.

.; JAFFEE, S. 2004. Standards and agro-food exports from developing countries: rebalancing the debate. World Bank Policy Research, Working Paper 3,348.

HIRSCH, R. 2005. São Francisco Valley and Irrigated Fruit Production. Rabobank International. F\&A Research Advisory. p. 32.

HOBBS, J. F.; FEARNE, A.; SPRIGGS, J. Incentive Structures for Food Safety and Quality Assurance: an International Comparison. Food Control, v. 13, Issue 2, Mar., p. 77-81, 2002

HOLLERAN, E., BREDAHL, M. E.; ZAIBET, L. Private incentives for adopting food safety and quality assurance. Food Policy, v. 24, p. 669-683, 1999.

IBRAF. 2004. Instituto Brasileiro de Frutas. Statistics. http://www.ibraf.org.br. (Accessed Mar. 2005).

ISO [International Organization for Standardization]. 1996. ISO/IEC Guide 2: General terms and their definitions concerning standardization and related activities. Geneva. 
JAHN, G.; SCHRAMM, M.; SPILLER, A. (2004a): Trust in Certification Procedures: an Institutional Economics Approach Investigating the Quality of Audits within Food Chains. In: INTERNATIONAL FOOD AND AGRIBUSINESS MANAGEMENT ASSOCIATION (IFAMA).

; SCHRAMM, M. SPILLER, A. The reliability of certification: quality labels as a consumer policy tool. Journal of Consumer Policy. v. 28, p. 53-73, 2005.

KLEINWECHTER, U.; GRETHE, H. The adoption of the EurepGAP standard by mango exporters in Piura, Peru. Paper prepared for presentation at the 26th Conference of the International Association of Agricultural Economists. Austrália, 2006.

LEE, G. C. H. Private food standards and their impact on developing countries. European commission. Trade Unit. p. 108, 2006.

LEVY, P. S; LEMESHOW, S. 1999. Sampling of populations: methods and applications. 3rd ed. Wiley \& Sons.

MARETTE, S.; CRESPI, J.M.; SCHIAVINA, A. The role of common labeling in a context of asymmetric information. European Review of Agricultural Economics. v. 26, n. 2, p. 167-178, 1999.

MEUWISSEN, M. P. M.; VELTHIUS, A. G. J.; HOGEVEEN, H.; HUIRNE, R. B. M. Technical and economic considerations about traceability and certification in livestock production chains. In: VELTHIUS, A. G. J.; HOGEVEEN, H.; HUIRNE, R. B. M. (Eds.). New approaches to food safety economics. Wageningen, p. 41-54, 2003.

MITCHELL, L. 2003. Economic theory and conceptual relationships between food safety and international trade. Chapter 2. In: INTERNATIONAL TRADE AND FOOD SAFETY ECONOMIC THEORY AND CASE STUDIES. Ed. Buzby, J. C. Agricultural Economic Report n. 828. p. 145. http://www.ers.usda.gov/publications/aer828/

NORMATIVE N. 011. Diretrizes gerais para produção integrada de uvas finas de mesa. Ministry of Agriculture, Food Supply, and Livestock. Brazil, 2003.

N. 012. Diretrizes gerais para produção integrada de manga. Ministry of Agriculture, Food Supply, and Livestock. Brazil, 2003.

N. 20. Aprovar as diretrizes gerais para a produção integrada de frutas e as normas técnicas para a produção integrada de frutas. Ministry of Agriculture, Food Supply, and Livestock. Brazil, 2001.

N. 58. Aditivos, coadjuvantes de fabricação, outras substâncias e recipientes. Diário Oficial da União de 26/10/2006, Seção 1, p. 5. Ministry of Agriculture, Food Supply, and Livestock. Brazil, 2006.

REGULATION (EEC) N. 1035/72. Common organization of the market in fruit and vegetables. Official Journal L 118, 20.5.1972, p. 1-17, 1972.

REGULATION (EC) N. 466/2001. Setting maximum levels for certain contaminants in foodstuffs. Official Journal L 77/1, 2001. 2004.

N. 2073/2005. Microbiological criteria for foodstuffs. Official Journal L 338/22, 22/12/2005. 
N. 396/2005. Establishes the maximum residue levels of pesticides in food and feed of plant and animal origin. Official Journal L 70/16, 2005.

N. 178/2002. General principles and requirements of food law, establishing the European food safety. Official Journal L 31/1, 2002.

N. 1862/2004. Marketing standard applicable to watermelons. Official Journal L 325, 28/10/2004, p. 17-22, 2004.

- N. 2789/1999. Marketing standard for table grapes. Official Journal L 336, 1999.

- N. 834/2007. Organic production and labeling of organic products and repealing regulation (EEC) No 2092/91. Official Journal L 189, 20.07.2007, p. 1-23, 2007.

SCHIEFER, G. 2003. Traceability and Certification in Food Quality Production: a Critical View. In: VelThiUS, A. G. J.; HOGEVEEN, H.; HUIRNE, R. B. M. (Eds.). New Approaches to Food Safety Economics. Wageningen.

SCHULZE, H.; ALBERSMEIR, F.; SPILLER, A.; JAHN, G. Checklist Governance: risk-oriented audits to improve the quality of certification standards in the food sector. 16th Annual World Forum and Symposium of Agribusiness, Food, Health, and Nutrition, IAMA Conference. Buenos Aires, Argentina, 2006.

USAID. The relationship of third-party certification (TPC) to sanitary and phytosanitary (SPS) measures and the international agri-food. Final report. Raise SPS Global Analytical Report n. 9, 2005.

USDA. United States standards for grades of mangoes. Agricultural marketing service. Fruit and vegetable division. Fresh products branch. Reprinted in Aug. 2007.

VALEXPORT. 2006. Há 18 anos Unindo Forças para o Desenvolvimento do Vale do São Francisco e da Fruticultura Brasileira, p. 17, Petrolina/PE, Brazil.

VITTI, A.; CINTRA, R. Certificação: o caminho para a qualidade. Hortifruti Brasil. Cepea/ESALQ/USP. Ano 1, n. 11, Mar., p. 8-11, 2003.

WTO (World Trade Organization). (2005): World Trade Report 2005. http://www.wto.org/ english/res_e/booksp_e/anrep_e/world_trade_report05_e.pdf. (Accessed Dec. 2007). 
